\title{
Uchwały zarządu i rady nadzorczej spółki akcyjnej w procedurze podwyższenia kapitału zakładowego w granicach kapitału docelowego
}

\section{Kapitał docelowy - geneza, istota, założenia}

Wysokość kapitału zakładowego w spółce akcyjnej jest, zgodnie z art. 304 § 1 pkt4 Kodeksu spółek handlowych (dalej: k.s.h. $)^{1}$, jednym z obligatoryjnych elementów treści jej statutu. Zmiany wysokości kapitału zakładowego wymagają podejmowania odpowiednich działań przez organy spółki oraz, dla ich pełnego urzeczywistnienia, dokonania wpisu w rejestrze. Szczególnie procedury podwyższenia kapitału zakładowego odgrywają w spółkach akcyjnych znaczącą rolę. To właśnie poprzez ich zastosowanie spółka może pozyskiwać kapitał zewnętrzny na cele związane $\mathrm{z}$ finansowaniem kosztownych przedsięwzięć czy bieżącym rozwojem własnej działalności. Ustawodawca polski, odpowiadając na potrzeby praktyki życia korporacyjnego, wprowadził w k.s.h. uproszczony wobec zwykłego podwyższenia kapitału zakładowego (art. 430-441 k.s.h.) tryb podwyższenia kapitału zakładowego w spółce akcyjnej polegający na podwyższeniu kapitału zakładowego w granicach kapitału docelowego (art. 444-4471 k.s.h.). Zastosowanie tej procedury eliminuje konieczność zwoływania i odbywania walnego zgromadzenia w każdym przypadku, w którym sytuacja wymaga szybkiego podjęcia decyzji o podwyższeniu kapitału zakładowego ${ }^{2}$.

Instytucja kapitału docelowego została do polskiego prawa wprowadzona dnia 1 stycznia 2001 r. wraz z wejściem w życie k.s.h. Ustawodawca polski wzorował się tutaj w dużym stopniu na rozwiązaniu przyjętym w niemieckiej ustawie akcyjnej (Aktiengesetz) $)^{3}$. Podwyż-

1 Dz.U.z 2000 r. nr 96, poz. 1037.

2 V. M. Romanowski et al., System prawa prywatnego. Prawo spótek kapitatowych, t. 17B, Warszawa 2010, s. 730-731; A. Radwan, Prawo poboru w spótce akcyjnej, Warszawa 2004, s. 326-405; S. Sołtysiński et al., Kodeks spótek handlowych. Komentarz, Warszawa 2008, komentarz do art. $444, \mathrm{Nb} 1$.

3 Aktiengesetz vom 6. September 1965 (BGB1. I S. 1089), §§ 202-206-Genehmigtes Kapital. 
szenie kapitału zakładowego spółki akcyjnej w ramach tej procedury jest jednym z przykładów świadomego poszerzania kompetencji organów wykonawczych i nadzorczych spółki $^{4}$ (zarządu i rady nadzorczej), nie wpływającym zarazem na zakres kompetencji walnego zgromadzenia ${ }^{5}$. Podstawę dla zastosowania tego trybu stanowi zawsze odpowiednie postanowienie zawarte $\mathrm{w}$ statucie spółki (art. 444 § 1 k.s.h.). Postanowienie to może być wprowadzone już do pierwotnej treści statutu, może także zostać do niego dodane poprzez uchwałę walnego zgromadzenia podjętą $\mathrm{w}$ trybie i na zasadach określonych w art. 445 k.s.h. Należy przyjąć - w związku z konstytutywnym charakterem zarówno wpisu spółki do rejestru, jak i wpisu rejestrującego zmianę statutu - że dniem wejścia w życie danego postanowienia statutowego jest dzień jego rejestracji ${ }^{6}$. Uprawnienie do podwyższania kapitału zakładowego w granicach kapitału docelowego może być udzielone jednorazowo na okres nie dłuższy niż trzy lata. Udzielenie kolejnego upoważnienia wymaga zmiany statutu (art. 444 § 2 k.s.h.). Wysokość kapitału docelowego nie może przekraczać trzech czwartych kapitału zakładowego spółki na dzień udzielenia upoważnienia. Zarząd nie ma obowiązku skorzystania z przyznanego mu uprawnienia. Postanowienia statutu lub uchwały walnego zgromadzenia obligujące zarząd do podwyższenia kapitału zakładowego w granicach kapitału docelowego są nieważne z mocy prawa $^{7}$. Należy jednak mieć na uwadze, iż walne zgromadzenie dysponuje prawem do odwołania członków zarządu w każdym czasie ${ }^{8}$. Przepisy art. 444 k.s.h. wprowadzają kilka ograniczeń związanych z wydawanymi przez zarząd akcjami (§§ 4-7). O wszelkich sprawach związanych z podwyższeniem kapitału zakładowego w granicach kapitału docelowego decyduje już zarząd (art. $446 \S 1$ zd. 1 k.s.h.). W pewnych przypadkach musi on jednak uzyskać zgodę rady nadzorczej czy nawet walnego zgromadzenia na podejmowane przez siebie czynności.

4 Więcej na temat zagrożeń z tym związanych v. M. Lutter et al., Kölner Kommentar zum Aktiengesetz, Kolonia 1995, s. 375 i n.; R. Pennington, Company Law, Londyn 2001, s. 741 i n.; A. Radwan, Ochrona akcjonariuszy a obowiqzki informacyjne zarzadu w zwiqzku z uchwaleniem $i$ wykorzystaniem kapitatu docelowego, „Kwartalnik Prawa Prywatnego” 2005 nr 1, s. 219 i n.

5 M. Romanowski, Podwyższenie kapitatu zaktadowego w granicach kapitatu docelowego, „Przegląd Prawa Handlowego" 2003 nr 2, s. 28.

6 V. S. Sołtysiński et al., Komentarz..., komentarz do art. 444, Nb 12; A. Kidyba, Kodeks spótek handlowych. Komentarz, t. 2, Warszawa 2007, s. 702; A. Nowacki, Upoważnienie zarzqdu do podwyższania kapitatu zaktadowego, „Prawo Spólek” 2008 nr 7-8, s. 15; M. Romanowski (Kapitat docelowy, „Przegląd Prawa Handlowego” 2002 nr 8, s. 6), twierdzi, że data początkowa może być określona odmiennie w treści upoważnienia.

7 M. Romanowski, Podwyższenie..., s. 25; cf. M. Goszczyk, Zmiany statutu i kapitatu w spótce akcyjnej. Art. 430-458 KSH. Komentarz, Warszawa 2009 s. 432.

8 Uprawnienie to może zostać ograniczone przez statut, którego postanowienia dopuszczają odwołanie członka zarządu tylko w przypadku wystąpienia ważnych powodów. $V$. art. $370 \S 2$ k.s.h. 
\begin{tabular}{l|l|l} 
Uchwaty zarzadu i rady nadzorczej... & 79
\end{tabular}

\section{Rodzaje uchwal podejmowanych przez zarząd i radę nadzorczą w procedurze podwyższenia kapitału zakładowego w granicach kapitału docelowego}

\section{Pojęcie uchwały i klasyfikacja uchwał zarządu i rady nadzorczej w procedurze pod- wyższenia kapitału zakładowego w granicach kapitału docelowego}

Podstawową formą działania organów osoby prawnej ${ }^{9}$ (zob. art. 38 k.c.) jest uchwała ${ }^{10}$. W procedurze podwyższenia kapitału zakładowego w granicach kapitału docelowego w tej właśnie formie podejmowane są decyzje zarządu i rady nadzorczej. Zasadniczo forma uchwały właściwa jest dla organów kolegialnych, jednakże ustawodawca, posługując się pojęciem „uchwała” w przepisie art. $446 § 1$ zd. 1 k.s.h., zdaje się przesądzać o tym, że nawet w przypadku zarządu jednoosobowego decyzja o podwyższeniu kapitału zakładowego jest traktowana w obrocie prawnym jak uchwała ${ }^{11}$. Decydujące znaczenie ma tutaj jednak rozróżnienie oświadczenia woli i czynności prawnej. Oświadczenie woli jedynego członka zarządu jest w tym przypadku jedynie częścią czynności prawnej dokonywanej przez spółkę ${ }^{12}$.

W ramach procedury podwyższenia kapitału zakładowego spółki akcyjnej w granicach kapitału docelowego można wyróżnić następujące rodzaje uchwał zarządu i rady nadzorczej:

1) uchwała zarządu o podwyższeniu kapitału zakładowego w granicach kapitału docelowego, podjęta na podstawie i w granicach statutowego upoważnienia, zastępująca uchwałę walnego zgromadzenia (art. $446 \S 1$ zd. 1 k.s.h.),

2) uchwała rady nadzorczej w procedurze współdziałania z zarządem w ramach podwyższenia kapitału zakładowego w granicach kapitału docelowego - dotyczy przede wszystkim ustalenia ceny emisyjnej i wydania akcji w zamian za aporty (art. $446 \S 2$ k.s.h.) i innych spraw zawartych w statucie (art. $446 \S 1$ zd. 2 k.s.h.),

3) uchwała zarządu w sprawie pozbawienia prawa poboru w całości lub w części wymagająca zgody rady nadzorczej i wynikająca $z$ konkretnego upoważnienia udzielonego przez walne zgromadzenie w drodze uchwały odpowiadającej warunkom $z$ art. 433 § 2 k.s.h. (art. 447 § 2 k.s.h.),

4) uchwała rady nadzorczej w procedurze współdziałania $z$ zarządem w ramach pozbawienia prawa poboru w całości lub w części (art. 447 § 2 k.s.h.).

9 V K.A. Dadańska, Dziatanie osoby prawnej, Warszawa 2006, s. 71 i n.

10 Co do pojęcia uchwały v. P. Grzesiok, Pojęcie i charakter prawny uchwaty organu spótdzielni, „Kwartalnik Prawa Prywatnego” 2005 nr 1, s. 165 i n.; E. Drozd et al., System prawa prywatnego, t. 2, Warszawa 2008, s. 182-183.

11 Co do uchwał zgromadzeń w spółkach jednoosobowych cf. P. Antoszek, Cywilnoprawny charakter uchwat wspólników spótek kapitatowych, Warszawa 2007, s. 368 i n.; A. Kidyba, Spótka z ograniczonq odpowiedzialnościq. Komentarz, Warszawa 2002, s. 238.

12 P. Antoszek, op. cit., s. 378. 
$80 \mid$ Przegląd Prawniczy Uniwersytetu im. Adama Mickiewicza

\section{Uchwały zarządu}

Uchwała, o której mowa w pkt. 1, jest podstawową czynnością podejmowaną przez zarząd realizujący swoją kompetencję do podwyższenia kapitału zakładowego w granicach kapitału docelowego. Przepis art. 446 k.s.h. nie określa trybu podjęcia rzeczonej uchwały. W związku z tym stosuje się tutaj wprost przepisy art. 371 § 2 i 3 k.s.h. Dotyczą one podejmowania uchwał przez zarząd wieloosobowy i stanowią, że uchwały zarządu zapadają bezwzględną większością głosów ${ }^{13}$, o ile statut nie stanowi inaczej. Ponadto do ważnego i skutecznego podjęcia uchwały wymagane jest uprzednie prawidłowe zawiadomienie wszystkich członków zarządu o posiedzeniu, na którym dana uchwała ma być podjęta ${ }^{14}$. Mimo, iż przepisy art. 371 k.s.h. nie przewidują szczególnej formy dla uchwał zarządu, to uchwała podjęta $\mathrm{w}$ sprawie podwyższenia kapitału zakładowego w granicach kapitału docelowego wymaga formy aktu notarialnego zgodnie $\mathrm{z}$ postanowieniem art. $446 \S 3$ k.s.h.

Pozbawienie prawa poboru w procedurze podwyższania kapitału zakładowego $\mathrm{w}$ granicach kapitału docelowego może nastąpić w dwojaki sposób. Po pierwsze - poprzez uchwałę walnego zgromadzenia powziętą zgodnie $\mathrm{z}$ art. 433 § 2 k.s.h. (uchwała taka dotyczy wtedy konkretnego podwyższenia kapitału zakładowego). Po drugie - statut może upoważniać zarząd do pozbawienia prawa poboru za zgodą rady nadzorczej. Upoważnienie takie musi wyraźnie wynikać z brzmienia statutu. Kompetencja do pozbawienia prawa poboru nie mieści się w ogólnej kompetencji do podwyższenia kapitału zakładowego wynikającej z art. 446 § 1 k.s.h. ${ }^{15}$.Zarząd podejmuje decyzję o pozbawieniu prawa poboru w formie uchwały (pkt. 3). Do wyłączenia lub ograniczenia prawa poboru przez zarząd wymagana jest zgoda rady nadzorczej (pkt. 4). Tego uprawnienia rady statut wyłączyć nie może. Wątpliwości w doktrynie wywołuje kwestia dopuszczalności zamieszczenia w statucie ogólnego postanowienia udzielającemu zarządowi kompetencji do pozbawiania prawa poboru w związku $\mathrm{z}$ każdym kolejnym podwyższeniem kapitału zakładowego ${ }^{16}$. Sporna jest także wykładnia przepisu art. $447 \S 2$ k.s.h., zgodnie z którym udzielenie takowego upoważnienia może nastąpić $\mathrm{w}$ drodze zmiany statutu (treść art. 447 § 2 in principio k.s.h.i surowe wymogi dotyczące większości z art. 433 § 2 k.s.h.). Niektórzy autorzy kwestionują więc dopuszczalność zamieszczenia takiej kompetencji

13 Powszechnie neguje się w doktrynie stosowanie do uchwał zarządu o podwyższeniu kapitału zakładowego przepisów o uchwałach walnego zgromadzenia o zmianie statutu (i podwyższeniu kapitału zakładowego) w drodze analogii. $C f$. art. $415 \S 3$ i 431 § 3a k.s.h.; v. M. Romanowski et al., System..., s. 752.

14 V. A. Kidyba, Kodeks..., s. 347-348.

15 M. Goszczyk, op. cit., s. 355.

16 V. M. Cejmer, Wytaczenie prawa poboru akcji na gruncie postanowień dyrektywy kapitatowej a instytucja kapitatu autoryzowanego, [w:] Europejskie prawo spótek, red. M. Cejmer, J. Napierała, T. Sójka, t. 2, s. 328; M. Goszczyk, op. cit., s. 355-356. 
w pierwotnej treści statutu ${ }^{17}$. Wyłączenie lub ograniczenie prawa poboru przez zarząd następuje w drodze uchwały podjętej zgodnie z regułami ogólnymi (art. 371 k.s.h.), statutowymi bądź regulaminowymi. Nie ma tutaj zastosowania, nawet w drodze analogii, art. $433 \S 2$ k.s.h. (wymóg większości czterech piątych głosów) ${ }^{18}$. Pozbawienie prawa poboru nie może dotyczyć tylko niektórych akcjonariuszy (tzw. wyłączenie selektywne) ${ }^{19}$.

\section{Uchwały rady nadzorczej}

Rada nadzorcza, współdziałając z zarządem spółki akcyjnej w procedurze podwyższenia kapitału zakładowego w granicach kapitału docelowego, działa in corpore podejmując uchwały. Taki sposób działania rady nadzorczej wynika z przepisu art. 390 $\S 1$ in principio k.s.h., który stanowi, że rada wykonuje swoje obowiązki kolegialnie ${ }^{20}$. Przepis ten nie statuuje zasady bezwzględnej, jednak w przypadkach opisanych wyżej w pkt. 2 i 4 znajduje zastosowanie. Sposób podejmowania uchwał przez radę nadzorczą regulują przepisy art. 388 k.s.h. Nie dotykając bliżej tej materii należy jedynie wspomnieć, że k.s.h. przewiduje kilka sposobów podejmowania takich uchwał, w tym także głosowanie w trybie tzw. kurendy czy za pomocą środków bezpośredniego porozumiewania się na odległość ${ }^{21}$. Uchwały rady nadzorczej w procedurze podwyższenia kapitału zakładowego w granicach kapitału docelowego nie mają, w odróżnieniu od niektórych uchwał zarządu, o których mowa w pkt. 1, charakteru samodzielnego. Rada nadzorcza jedynie wyraża zgodę na dokonanie przez zarząd czynności o oznaczonej treści. Wymóg wyrażenia takiej zgody może wynikać z przepisów k.s.h. bądź z postanowień statutu. Przepisy ustawy mają w tej materii charakter bezwzględnie albo względnie wiążący. Do tych pierwszych należy zaliczyć art. 447 § 1 zd. 2 k.s.h., który dotyczy wyłączenia prawa poboru. Pozbawienie prawa poboru w całości lub w części w związku z podwyższeniem kapitału zakładowego w granicach kapitału docelowego wymaga zasadniczo uchwały walnego zgromadzenia ${ }^{22}$. W związku jednak z dążeniem ustawodawcy do maksymalnego uproszczenia tej procedury, została stworzona możliwość wykorzystania innego sposobu wyłączenia prawa poboru. W sytuacji, gdy statut wyraźnie to przewiduje, może ono nastąpić poprzez podjęcie odpowiedniej uchwały przez zarząd za zgodą rady nadzorczej. Powyższa kompetencja rady nadzorczej nie może być wyłączona przez postanowienia

17 Tak: M. Goszczyk, op. cit., s. 356; odmiennie: A. Radwan, Prawo..., s. 365; M. Rodzynkiewicz, Kodeks spótek handlowych. Komentarz, Warszawa 2009, s. 976.

18 V. M. Romanowski, Kapitat docelowy a prawo poboru, „Przegląd Prawa Handlowego” 2003 nr 3, s. 7. 19 Odmiennie SN w wyroku V CKN 458/03.

20 V. J. Napierała, T. Sójka et al., Prawo spótek handlowych. Podręcznik akademicki, Warszawa 2011, s. 440-441.

21 V. P. Pinior, Szczególne sposoby podejmowania uchwat przez radę nadzorcza, [w:] Prawo handlowe XXI wieku. Czas stabilizacji, ewolucji czy rewolucji. Księga jubileuszowa prof. Józefa Okolskiego, red. M. Modrzejewska, Warszawa 2010, s. 779-793.

22 Materię tę reguluje przepis art. $433 \S 2$ k.s.h. 
statutowe, przez co przepis art. $447 \S 1 \mathrm{zd} .2$ k.s.h. - mimo iż stanowi w zasadzie przepis ius dispositioum - w części dotyczącej wymogu uzyskania zgody rady nadzorczej ma charakter bezwzględnie wiążący. Wynika to z potrzeby ochrony interesów akcjonariuszy, przede wszystkim w spółkach, w których zarząd zajmuje stosunkowo silną pozycję i konflikt agencyjny między właścicielami a zarządcami jest nasilony. Rada nadzorcza, stanowiąc co do zasady reprezentację czynnika właścicielskiego, ma w tym przypadku za zadanie ochronę interesów akcjonariuszy ${ }^{23}$. Przepisem względnie wiążącym, który przewiduje wymóg uzyskania zgody rady nadzorczej przez zarząd podejmujący uchwały w procedurze podwyższenia kapitału zakładowego w granicach kapitału docelowego, jest przepis art. $446 \S 2$ k.s.h. Dotyczy on podejmowania przez zarząd decyzji w sprawie ustalenia ceny emisyjnej akcji oraz wydania akcji w zamian za aporty. W tych przypadkach wymóg uzyskania zgody rady wynika z ustawy - jeżeli statut nie stanowi inaczej - i podyktowany jest potrzebą wzmocnienia ochrony akcjonariuszy przed nadużyciami ze strony zarządu poprzez udział organu składającego się z piastunów wybranych przez, co do zasady, czynnik właścicielski.

Spis wymienionych wyżej stanów faktycznych, w których do podjęcia uchwały przez zarząd w procedurze podwyższenia kapitału zakładowego w ramach kapitału docelowego wymagana jest zgoda rady nadzorczej, nie ma charakteru zamkniętego. Zgodnie z postanowieniem art. $446 \S 1$ zd. 2 k.s.h. zarząd decyduje o wszystkich sprawach związanych z podwyższeniem kapitału zakładowego, chyba że przepisy ustawy lub treść upoważnienia zawierają odmienne postanowienia. To właśnie $\mathrm{z}$ treści upoważnienia udzielonego zarządowi mogą wynikać inne wymogi uzyskania zgody rady nadzorczej ${ }^{24}$. Upoważnienie takie, jak wspomniano wyżej, zawarte jest wyłącznie w postanowieniach statutu spółki.

\section{Charakter prawny uchwał zarządu i rady nadzorczej spółki akcyjnej}

\section{Uchwała zarządu spółki akcyjnej a czynność prawna}

Badanie charakteru prawnego wskazanych wyżej uchwał należy oprzeć na sprawdzeniu, czy mieszczą się one w zakresie semantycznym pojęcia „czynność prawna”.

Definicja czynności prawnej zaproponowana przez Z. Radwańskiego, według którego jest to „skonstruowana przez system prawny czynność konwencjonalna podmiotu prawa cywilnego, której treść określa - co najmniej w podstawowym zakresie - jej konsekwencje prawne ${ }^{25}$ ", wydaje się być właściwa także na tle uchwał zarządu

23 V. A. Opalski, Rada nadzorcza w spótce akcyjnej, Warszawa 2006, s. 19 i n.

24 Przykładowo statutowe upoważnienie może wprowadzać wymóg zgody rady nadzorczej na podwyższenie kapitału zakładowego powyżej określonej kwoty; v. S. Sołtysiński et al., Kodeks..., komentarz do art. 446, Nb 19; M. Goszczyk, op. cit., s. 342.

25 Z. Radwański et al., System prawa prywatnego, t. 2, Warszawa 2008, s. 34. 
- organu spółki akcyjnej, podejmującego uchwałę o podwyższeniu kapitału zakładowego w granicach kapitału docelowego czy uchwałę o pozbawieniu prawa poboru w całości albo w części. Niewątpliwie uchwała jest czynnością konwencjonalną, gdyż na podstawie reguł prawnych aktom głosowania - czynnościom konwencjonalnym prostszym - dokonywanym przez członków organu spółki kapitałowej nadaje się nowy sens prawny ${ }^{26}$. Zgodnie $z$ założeniami teorii organów oraz jej normatywną podstawą zawartą w art. 38 k.c., działania zarządu niewyposażonego w podmiotowość prawa cywilnego, są przypisywane bezpośrednio osobie prawnej - spółce, która taką podmiotowość posiada. Podejmując stosowne działania, spółka dokonuje regulacji stosunków cywilnoprawnych, do jakich należy zaliczyć stosunek członkostwa w spółce akcyjnej (którego podstawą jest objęcie i posiadanie akcji spółki). Pośrednim skutkiem prawnym podjęcia uchwały o podwyższeniu kapitału zakładowego jest powstanie szeregu stosunków cywilnoprawnych między spółką a podmiotami przyjmącymi ofertę objęcia akcji. Bezpośrednim skutkiem prawnym jest natomiast aktualizacja prawa poboru przysługującego akcjonariuszom ${ }^{27}$. Może ona polegać zarówno na urzeczywistnieniu się prawa poboru in concreto, jak i na pozbawieniu bądź ograniczeniu tego prawa w danej sytuacji. Wynikiem podjęcia uchwały przez zarząd jest więc powstanie uprawnienia po stronie akcjonariuszy do objęcia akcji w podwyższonym kapitale zakładowym bądź pozbawienie ich takiego uprawnienia. Podejmowanie uchwały przez zarząd następuje w sposób i na warunkach przewidywanych przez prawo. Podstawą działań zarządu są wszakże odpowiednie przepisy k.s.h., jak i postanowienia statutu (głównie treść upoważnienia). Skutkowa koncepcja czynności prawnych, oparta na brzmieniu art. 56 k.c., również nie stoi na przeszkodzie uznaniu, że wskazane wyżej uchwały stanowią czynności prawne ${ }^{28}$. Owe skutki prawne zostały wskazane wyżej, a polegają na zmianie treści stosunków prawnych łączących spółkę z jej akcjonariuszami, jak również na powstaniu nowych stosunków prawnych między spółką a podmiotami obejmującymi akcje nowej emisji (nie będącymi dotychczas akcjonariuszami).

Niezbędnym składnikiem każdej czynności prawnej jest oświadczenie woli ${ }^{29}$. Pojęcie oświadczenia woli, czyli wyrażenia woli wywołania skutków prawnych przez osobę dokonującą czynności prawnej, jest zdefiniowane w art. 60 k.c. Należy przyjąć, że w przypadku uchwał oświadczenia woli mają dwojaki charakter. Po pierwsze przyjmuje się, że każdy z członków organu podejmującego uchwałę składa oświadczenie woli poprzez akt

26 V. Czynności konwencjonalne w prawie, praca zbiorowa, „Studia Prawnicze INP” $1972 \mathrm{nr}$ 33, s. 73 i n.; S. Wronkowska, Z. Ziembiński, Zarys teorii prawa, Poznań 1997, s. 30.

27 Odnośnie prawa poboru wynikającego ze stosunku obligacyjnego, tzw. prawa poboru ex contractu v. P. Grzejszczak, Prawo poboru akcji, Warszawa 1998, s. 10 i n.; A. Radwan, Prawo..., s. 118 i n.

28 V. M. Gutowski, Nieważność czynności prawnej, Warszawa 2008, s. 36 i n.

29 Cf. Ibidem, s. 19; R. Longchamps de Berier, Zobowiqzania, Poznań 1948, s. 16. 
głosowania $^{30}$. Po drugie akt woli organu jako całości również jest oświadczeniem woli, które w ostatecznym rozrachunku przypisywane jest samej spółce ${ }^{31}$.

Inne elementy konstytutywne czynności prawnej ${ }^{32}$ dokonywanej przez zarząd spółki akcyjnej, a polegającej na podjęciu uchwały o podwyższeniu kapitału zakładowego lub pozbawieniu prawa poboru, to przede wszystkim konstytutywny wpis podwyższenia kapitału zakładowego do rejestru przedsiębiorców. Skutek prawny, jakim jest powstanie prawa poboru in concreto czy jego pozbawienie, czy ograniczenie powstaje pod warunkiem rejestracji podwyższenia ${ }^{33}$. Również zgoda rady nadzorczej musi być w pewnych przypadkach uznana za wymóg dojścia do skutku uchwały o podwyższeniu kapitału zakładowego.

W związku z powyższym, uzasadnione jest twierdzenie, że uchwały zarządu podejmowane w procedurze podwyższania kapitału zakładowego w granicach kapitału docelowego stanowią czynności prawne ${ }^{34}$.

\section{Charakter prawny uchwały rady nadzorczej wyrażającej zgodę na dokonanie przez zarząd oznaczonej czynności}

Większe wątpliwości wywołuje z pewnością charakter prawny wskazanych wyżej uchwał rady nadzorczej. W przypadku kapitału docelowego uprawnienia rady nie mają bowiem charakteru samodzielnego. To zarząd decyduje o podwyższeniu kapitału zakładowego i jego zasadnicze kompetencje nie mogą być cedowane na radę nadzorczą. Rada pełni w tej procedurze funkcję związaną ze współdecydowaniem o określonych ustawą lub statutem aspektach podwyższenia kapitału. Uchwale rady zawsze towarzyszy odpowiednia uchwała zarządu, a decyzja rady nadzorczej ma charakter zgody na dokonanie oznaczonej czynności przez zarząd (co wynika chociażby z brzmienia art. $446 \S 2$ i 447 $\S 2$ k.s.h.).

Do skutków braku zgody rady nadzorczej na dokonanie przez spółkę czynności prawnej odnoszą się przepisy art. 17 k.s.h. Stanowi on, że czynność dokonana bez wymaganej przepisami ustawy zgody jest nieważna, natomiast czynność dokonana bez zgody wymaganej wyłącznie postanowieniami statutu jest ważna, co nie wyklucza jednak odpo-

30 Z. Radwański, System..., s. 183.

$31 \mathrm{~V}$. E. Płonka, Uczestnictwo osób prawnych w walnym zgromadzeniu spótki kapitatowej, „Państwo i Prawo"1990, nr 1, s. 91.

32 Cf. A. Wolter, Problematyka ogólna czynności prawnych w Kodeksie cywilnym, „Państwo i Prawo” 1964 nr 11, s. 67; Z. Radwański, op. cit., s. 32.

33 Tak: A. Radwan, Prawo poboru..., ss. 134, 137.

34 Pogląd odmienny, odmawiający uchwałom organów spółek kapitałowych charakteru czynności prawnych prezentuje m.in. J. Frąckowiak, Handlowe czynności kreujacce, „Przegląd Prawa Handlowego" 2008 nr 12, s. 11 i n. oraz D. Kulgawczuk i R.L. Kwaśnicki, Cywilnoprawne aspekty wadliwości uchwat zarzadu spótki kapitatowej - uwagi de lege lata $i$ wnioski de lege ferenda, „Prawo Spółek” 2008 nr 6, s. 13-14. 
wiedzialności członków zarządu wobec spółki. Wyrażenie przez radę nadzorczą zgody wymaganej ustawowo jest możliwe w terminie dwóch miesięcy od dnia złożenia oświadczenia przez spółkę (art. 17 § 2 k.s.h.) czyli od dnia podjęcia uchwały przez zarząd.

Stosowanie przepisu art. 17 k.s.h. do uchwał rady nadzorczej podejmowanych w procedurze podwyższenia kapitału zakładowego w granicach kapitału docelowego nie powinno budzić wątpliwości ${ }^{35}$. Zatem brak zgody rady nadzorczej na ustalenie ceny emisyjnej akcji (a także wadliwość podjętej przez radę w tym przedmiocie uchwały) ${ }^{36}$, objęcie akcji w zamian za aporty czy wyłączenie prawa poboru skutkuje nieważnością czynności prawnej, jaką jest uchwała o podwyższeniu kapitału zakładowego czy wyłączeniu prawa poboru. Skutek w postaci nieważności następuje po upływie terminu dwóch miesięcy od podjęcia uchwały przez zarząd ${ }^{37}$.

Wskazane wyżej uchwały rady nadzorczej stanowiące zgodę na dokonanie przez zarząd czynności prawnej o oznaczonej treści nie mogą samodzielnie wywoływać skutków prawnych w sferze praw akcjonariuszy czy osób trzecich. $Z$ pewnością nie stanowią więc one czynności prawnych o charakterze samoistnym. Przedstawiciele nauki prawa rozmaicie klasyfikują owe uchwały przyjmując, że mogą być one postrzegane jako: część składowa czynności prawnej ${ }^{38}$, pełnomocnictwo organizacyjne ${ }^{39}$ bądź warunek prawny (conditio iuris) $)^{40}$. W najnowszej literaturze pojawiło się również stanowisko wyrażone przez S. Sołtysińskiego, według którego uchwała rady nadzorczej w przedmiocie wyrażenia zgody na dokonanie czynności prawnej przez zarząd „stanowi pomocniczą, lecz odrębną czynność prawną"41. Autor ten wskazuje na argumenty natury praktycznej związane $\mathrm{z}$ wymogami stawianymi uchwale rady nadzorczej co do formy oraz $\mathrm{z}$ wadliwością uchwały stanowiącej zgodę ${ }^{42}$.

35 Cf. S. Sołtysiński et al., Kodeks.., komentarz do art. 446, Nb 17-18; M. Romanowski, Podwyższenie..., s. 26. Ten ostatni autor proponuje odpowiednie stosowanie art. 17 k.s.h.

36 V. R. Czerniawski, Kodeks spótek handlowych. Przepisy o spótce akcyjnej. Komentarz, Warszawa 2004, s. 511.

37 Należy przyjać, choć nie jest to jednolite stanowisko doktryny, że w trakcie dwumiesięcznego terminu do wyrażenia zgody czynność prawna dotknięta jest sankcją bezskuteczności zawieszonej. Tak: Z. Radwański, op. cit., s. 454; S. Czepita, Z. Kuniewicz, Spór o konwalidację nieważnych czynności prawnych, „Państwo i Prawo” 2002 nr 9, s. 84-86; wyrok III CSK 304/08.

38 V. Z. Kuniewicz, S. Czepita, Reprezentacyjna funkcja zarzqdu spótki kapitatowej, Szczecin 2005, s. 182.

39 V. T. Dziurzyński et al., Kodeks handlowy z komentarzem i skorowidzem, Łódź 1994, s. 246247; E. Płonka, Umocowanie zarzq̨du spótki kapitatowej do jej reprezentacji, „Nowe Prawo” 1990 nr 4-6, s. 3 i n.

$40 \mathrm{~V}$. P. Antoszek, Charakter prawny uchwat zgromadzeń spótek kapitatowych zezwalających na dokonanie czynności prawnych przez spótkę, „Przegląd Prawa Handlowego” 2006 nr 7, s. 34-35.

41 S. Sołtysiński, Charakter prawny uchwat rady nadzorczej, [w:] Prawo..., red. M. Modrzejewska, s. 955-956.

42 Ibidem, s. 956. 
86 | Przegląd Prawniczy Uniwersytetu im. Adama Mickiewicza

\section{Wadliwość uchwał zarządu i rady nadzorczej podejmowanych w procedurze podwyższania kapitału zakładowego $w$ granicach kapitału docelowego}

Wadliwość wskazanych wyżej uchwał, klasyfikowanych jako czynności prawne bądź ich części składowe (ewentualnie tzw. conditiones iuris), może, w uproszczeniu, polegać na naruszeniu norm prawa powszechnie obowiązującego, naruszeniu postanowień statutu spółki bądź regulaminu organu lub sprzeczności z zasadami współżycia społecznego. Ustawodawca nie przewiduje odrębnego trybu zaskarżania wadliwych uchwał zarządów i rad nadzorczych spółek kapitałowych, odmiennie aniżeli w przypadku uchwał zgromadzeń wspólników i walnych zgromadzeñ ${ }^{43}$. Dlatego dla oceny skutków wadliwości danej uchwały konieczne jest zastosowanie przepisów k.c. o czynnościach prawnych w oparciu o odesłanie $z$ art. 2 k.s.h. ${ }^{44}$.

Sprzeczność uchwały z normami prawa powszechnie obowiązującego (ustawodawca posługuje się dla ich oznaczenia pojęciem „ustawa” w art. $58 \S 1$ k.c.) skutkuje, na podstawie art. 58 § 1 k.c. w zw. z art. 2 k.s.h., jej nieważnością. Tak wadliwa uchwała (uchwały) jest nieważna ab initio i nie wywoluje takich skutków prawnych, jakie miałyby wynikać z jej treści. Przepisy k.s.h. nie przewidują także konwalidacji takich czynności. Niektórzy przedstawiciele doktryny przyjmują, że skutek o charakterze sanującym może być wywołany przez wpisanie podwyższenia kapitału zakładowego opartego na nieważnej uchwale zarządu (rady nadzorczej) do rejestru przedsiębiorców ${ }^{45}$. Sąd rejestrowy, rozpatrując wniosek o rejestrację podwyższenia kapitału zakładowego, bada, zgodnie z art. 23 ust. 1 ustawy o Krajowym Rejestrze Sądowym (dalej: u.k.r.s.) ${ }^{46}$, zgodność formy i treści dokumentów z przepisami prawa ${ }^{47}$. Zakres kognicji sądu rejestrowego, jak i brak wyraźnej normy prawnej, która uzasadniałaby twierdzenie o dopuszczalności konwalidacji nieważnej uchwały przez ten sąd, stanowią argumenty przeciw temu twierdzeniu ${ }^{48}$. Zapewnienie instrumentów prawnych pozwalających na stwierdzenie nieważności uchwały także po wpisie podwyższenia kapitału do rejestru jest zarazem istotne $\mathrm{z}$ punktu widzenia ochrony interesów akcjonariuszy (przede wszystkim z uwagi na to, iż mogą oni

43 V. S. Sołtysiński, A. Opalski, Zaskarżanie uchwat zarządów i rad nadzorczych spótek kapitatowych, „Przegląd Prawa Handlowego” 2010 nr 11, s. 5 i n.; wyrok II CSK 449/09.

44 V. M. Pazdan, Kodeks spótek handlowych a kodeks cywilny, „Państwo i Prawo” 2001 nr 2, s. 30-31; M. Bieniak et al., Kodeks spótek handlowych. Komentarz, Warszawa 2011, komentarz do art. 446 $\mathrm{Nb} 5$.

45 Rozwiązanie takie wskazuje jako słuszne S. Sołtysińskiet al., Kodeks..., komentarz do art. 446, $\mathrm{Nb} 20$. Autor uzasadnia swoje twierdzenie tym, iż sąd rejestrowy może wszcząć postępowanie naprawcze.

46 Dz.U. z 1997 r. nr 127, poz. 769 z późn. zm.

47 V. E. Marszałkowska-Krześ, Ustawa o Krajowym Rejestrze Sąowym. Komentarz, Warszawa 2001, komentarz do art. 23, Nb 4.

48 Cf. A. Radwan, Prawo..., s. 407-408. 
w ogóle nie być świadomi tego, że dane podwyższenie kapitału zakładowego zostało zarejestrowane). Ponadto sama u.k.r.s przewiduje możliwość wykreślenia danych niedopuszczalnych ze względu na obowiązujące przepisy prawa (w tym także postanowienia statutu) na podstawie art. 12 ust. 3.

Wątpliwości w doktrynie wywołuje natomiast sankcja wadliwości uchwał zarządów i rad nadzorczych sprzecznych ze statutem spółki. W przypadku uchwał podejmowanych w procedurze podwyższenia kapitału zakładowego w granicach kapitału docelowego najczęstsze naruszenia postanowień statutu polegają na przekraczaniu granic umocowania przez zarząd. Część przedstawicieli doktryny przyjmuje, że uchwały organów menedżerskich sprzeczne $z$ postanowieniami statutu (umowy) spółki są nieważne ${ }^{49}$. Prawnym uzasadnieniem dla przyjęcia takiej sankcji są przepisy art. 35, 38 i 58 k.c. stosowane w związku z odesłaniem z art. 2 k.s.h. Zgodnie $\mathrm{z}$ art. 35 in fine k.c. w wypadkach i zakresie przewidzianym w przepisach prawa organizację i sposób działania osoby prawnej reguluje także jej statut, zaś zgodnie z art. 38 k.c. osoba prawna działa przez swoje organy w sposób przewidziany w ustawie i opartym na niej statucie. Sprzeczność treści czynności prawnej z postanowieniami statutu ma więc stanowić naruszenie przepisów art. 35 i 38 k.c. i, w związku z tym iż przepisy szczególne nie przewidują łagodniejszej sankcji wadliwości, należy uznać taką czynność za nieważną ${ }^{50}$. Zdaniem przeciwników takiego stanowiska sprzeczność uchwały ze statutem spółki nie powoduje jej nieważności. K. Bilewska wskazuje, że przepisy art. 35 i 38 k.c., których naruszenie miałoby być podstawą nieważności uchwały sprzecznej ze statutem „mają charakter organizacyjny i bardzo ogólny (ustrojowy)" ${ }^{51}$. Zdaniem tej autorki, popartym przykładem z orzecznictwa $^{52}$, nie ma podstaw prawnych do uznania, że uchwały organów menedżerskich sprzeczne ze statutem są obarczone jakąkolwiek sankcją wadliwości ${ }^{53}$. Wskazane rozbieżności w doktrynie i orzecznictwie wskazują na potrzebę dokładnego uregulowania tego zagadnienia przez ustawodawcę.

Wątpliwości budzi również kwalifikacja uchwał sprzecznych wyłącznie z postanowieniami regulaminów organów spółki ${ }^{54}$. De lege lata uznać należy, że czynności takie są ważne, co nie wyklucza jednak zastosowania instrumentów odpowiedzialności organizacyjnej funkcjonariuszy. Takie ukształtowanie sankcji wadliwości najlepiej odpowiada

49 S. Sołtysiński, A. Opalski, Zaskarżanie..., s. 15. Autorzy ci wskazują, że statut spółki ma charakter quasi-normatywny, wiążący wszystkich akcjonariuszy i członków organów, a naruszenie statutu skutkuje powstaniem odpowiedzialności odszkodowawczej funkcjonariuszy.

50 S. Sołtysiński, A. Opalski, Zaskarżanie..., s. 15.

51 K. Bilewska, Przestanki powzięcia uchwaty rady nadzorczej spótki kapitatowej a jej zaskarżanie, „Monitor Prawniczy” 2010 nr 6, s. 306.

52 Wyrok I ACa 200/08.

53 K. Bilewska, Przestanki..., s. 306; J. Frąckowiak et al., Kodeks spótek handlowych. Komentarz, Warszawa 2008, s. 819 i 838.

54 V. A. Opalski, Rada..., s. 319-320. 
potrzebom ochrony interesów akcjonariuszy, gdyż zazwyczaj nie są oni zaznajomieni $\mathrm{z}$ treścią regulaminu np. zarządu ${ }^{55}$.

Przepis art. $422 \S 1$ k.s.h. dotyczący powództwa o uchylenie uchwały walnego zgromadzenia ustanawia sankcję wzruszalności (w drodze prawomocnego orzeczenia sądu) uchwał sprzecznych z dobrymi obyczajami i godzących w interes spółki lub mających na celu pokrzywdzenie akcjonariusza. Przepis ten nie znajduje zastosowania do uchwał zarządów i rad nadzorczych, jednak uchwały te, jako czynności prawne bądź ich części składowe, podlegają ocenie zgodności z zasadami współżycia społecznego (art. 58 § 2 k.c. w zw. $\mathrm{z}$ art. 2 k.s.h.). Z uwagi na daleko idące podobieństwo zakresu pojęciowego klauzul generalnych, jak i cel uchwały zarządu o podwyższeniu kapitału zakładowego, treść art. $422 \S 1$ k.s.h. może stanowić zatem wskazówkę interpretacyjną dla sądu badającego zgodność uchwały zarządu czy rady nadzorczej z zasadami współżycia społecznego ${ }^{56}$.

\section{Zaskarżanie wadliwych uchwał zarządu i rady nadzorczej podjętych $\mathrm{w}$ procedurze podwyższenia kapitału zakładowego $\mathrm{w}$ granicach kapitału docelowego}

Jednym ze wskazywanych w piśmiennictwie celów wprowadzenia instytucji kapitału docelowego było zapobieżenie zaskarżaniu uchwał o podwyższeniu kapitału zakładowego $^{57}$. W związku z tym, że k.s.h. nie wprowadza odrębnego reżimu zaskarżania uchwał zarządów i rad nadzorczych zastosowanie znajdą albo w drodze analogii przepisy o zaskarżaniu uchwał walnych zgromadzeń, albo - poprzez odesłanie z art. 2 k.s.h. - przepisy k.c. i k.p.c.

Problem eliminowania wadliwych uchwał zarządów i rad nadzorczych $z$ obrotu prawnego poruszano w piśmiennictwie także w kontekście kapitału docelowego ${ }^{58}$. Większość autorów jest zgodna, że do uchwał tych nie znajdują zastosowania, nawet w drodze analogii, przepisy o zaskarżaniu uchwał akcjonariuszy ${ }^{59}$. A. Radwan proponuje jednak, aby

55 Cf. ibidem, s. 319.; A. Opalski zajmuje stanowisko, według którego sprzeczność uchwały rady nadzorczej z regulaminem rady skutkuje nieważnością tylko w przypadku, gdy regulamin został przyjęty przez walne zgromadzenie, a naruszenie regulaminu nie ma charakteru uchybienia mniejszej wagi. W przypadku naruszenia regulaminu przyjętego przez samą radę, uchwała jest ważna.

56 V. M. Wilejczyk, Stosowanie przepisów kodeksu cywilnego do wadliwych uchwat zgromadzeń wspólników spótek kapitalowych, „Przegląd Prawa Handlowego” 2012 nr 4, s. 26-27; S. Sołtysiński, Nieważne i wzruszalne uchwaty zgromadzeń spótek kapitatowych, „Przegląd Prawa Handlowego" 2006 nr 1, s. 15.

57 V. M. Romanowski, Kapitat..., s. 2; S. Sołtysiński et al., Kodeks..., komentarz do art. 444, Nb 1.

58 V. A. Radwan, Ochrona..., s. 219 i n.; S. Soltysiński, A. Opalski, Zaskarżanie..., s. 6.

59 V. S. Sołtysiński, A. Opalski, Zaskarżanie..., s. 17-18; K. Bilewska, Przestanki powzięcia uchwat rady nadzorczej spótki kapitatowej a jej zaskarżanie, „Monitor Prawniczy” 2010 nr 6, s. 307-308; M. Jagielska, Kontrola prawidtowości uchwat rady nadzorczej, „Przegląd Prawa Handlowego” $2006 \mathrm{nr} 2$, s. 19. 
do uchwał zarządu zastępujących uchwały walnego zgromadzenia (art. $446 \S 1$ k.s.h.) stosować odpowiednio przepisy o terminach do wytoczenia powództwa o stwierdzenie nieważności bądź uchylenie uchwały walnego zgromadzenia ${ }^{60}$. Zaprezentowany wyżej pogląd nie znajduje jednak uzasadnienia w przepisach ustawy.

Podstawowym środkiem zaskarżania uchwał zarządów i rad nadzorczych pozostaje więc powództwo o ustalenie istnienia albo nieistnienia stosunku prawnego lub prawa $\mathrm{z}$ art. 189 k.p.c. Mimo usytuowania podstawy tej instytucji w ustawie proceduralnej, ma ona charakter materialnoprawny ${ }^{61}$. Wykorzystanie instytucji powództwa o ustalenie do zaskarżania uchwał zarządu i rady nadzorczej podejmowanych w procedurze podwyższenia kapitału zakładowego w granicach kapitału docelowego albo do stosunków prawnych, które powstały bądź miały powstać w związku z wykonaniem takich uchwał, budzi jednak wątpliwości natury praktycznej. Po pierwsze należy wskazać na brak dokładnego określenia podmiotów legitymowanych („każdy, kto ma w tym interes prawny”). Pomijając rozważania nad istotą pojęcia interesu prawnego ${ }^{62}$, należy wskazać, że w porównaniu z katalogiem podmiotów z art. 422 k.s.h. zakres osób legitymowanych do wytoczenia powództwa o ustalenie jest bardzo szeroki, co może zagrażać stabilności stosunków korporacyjnych $^{63}$. Po drugie warto zastanowić się nad problemem braku ograniczeń czasowych do wytoczenia powództwa o ustalenie. Jest to chyba największy mankament tej instytucji, który stanowi poważne zagrożenie dla bezpieczeństwa obrotu. Skutki prawne uwzględnienia przez sąd powództwa o ustalenie nieważności uchwały, wytoczonego po wielu latach od jej podjęcia mogą być skrajnie niekorzystne. W literaturze proponuje się stosowanie w takich przypadkach art. 5 k.c., jednak zarzut nadużycia prawa nie zawsze musi być uwzględniony przez sąd ${ }^{64}$. Po trzecie wyrok uwzględniający powództwo o ustalenie ma moc wiążącą jedynie między stronami procesu ${ }^{65}$, co z jednej strony może być postrzegane jako korzyść dla stabilności obrotu gospodarczego, a z drugiej zdecydowanie utrudnia trwałe eliminowanie wadliwych uchwał i ich skutków prawnych $z$ obrotu. De lege lata należy jednak przyjąć, że instytucja powództwa o ustalenie z art. 189 k.p.c. znajduje zastosowanie do wadliwych uchwał zarządów i rad nadzorczych spółek kapitałowych podejmowanych w procedurze podwyższania kapitału zakładowego w granicach kapitału docelowego i w obecnym stanie prawnym stanowi podstawowy instrument ich zaskarżania. Należy dodać, iż powód może wystąpić także z wnioskiem o zabezpieczenie powództwa (art. 730 k.p.c.), przy czym musi wykazać interes prawny. Zabezpieczenie

60 Czyli przepisy art. 424 i 425 § 2 i 3 k.s.h.; A. Radwan, Prawo..., s. 450-451.

61 V. E. Rudkowska-Ząbczyk et al., Postepowanie cywilne, Warszawa 2008, s. 155.

62 V. A. Wilczyńska, Interes prawny i jego granice w posteppowaniu cy wilnym, „Palestra” $2010 \mathrm{nr}$ 9-10, s. 33-35.

63 Cf. S. Sołtysiński, A. Opalski, Zaskarżanie..., s. 7; B. Czech et al., Kodeks postępowania cywilnego. Komentarz, t. 1, Warszawa 2001, s. 818.

64 V. S. Soltysiński, A. Opalski, Zaskarżanie..., s. 7-8.

65 V. A. Opalski, Rada..., s. 327. 
może polegać w szczególności, w przypadku uchwał organów spółek kapitałowych, na wstrzymaniu wykonania uchwały będącej przedmiotem powództwa ${ }^{66}$.

W doktrynie wskazuje się także na powództwo negatoryjne (actio negatoria) jako możliwy sposób zapobiegania wystąpieniu skutków prawnych wynikających z wadliwych uchwał o podwyższeniu kapitału zakładowego ${ }^{67}$. Żądaniem powoda jest w takim przypadku „zaniechanie podjęcia albo wykonania uchwały przez zarząd ${ }^{68 ”}$. Innym sposobem ochrony interesów pokrzywdzonych akcjonariuszy może być standardowe powództwo odszkodowawcze (art. 415 k.c.), przy czym niezbędnym jest tutaj wykazanie winy spółki (wina organu - art. 416 k.c.), poniesionej szkody i adekwatnego związku przyczynowego.

\section{Zaskarżanie uchwał organów menedżerskich spółek kapitałowych w prawie hiszpańskim i włoskim}

Ustawodawcy innych państw europejskich często decydują się na odrębną regulację instytucji zaskarżania uchwał organów menedżerskich spółek kapitałowych. Dla przykładu warto wskazać tutaj na rozwiązania przyjęte w Hiszpanii i we Włoszech.

Hiszpańska ustawa o spółkach kapitałowych z 2 lipca 2010 r. (Ley de sociedades de capital ${ }^{69}$ przewiduje odrębny reżim zaskarżania uchwał rady administrującej (el consejo de administración) ${ }^{70} \mathrm{w}$ art. 251. Ustawodawca hiszpański odróżnia uchwały nieważne (los acuerdos nulos) od wzruszalnych (los acuerdos anulables), wprowadza ograniczony krąg podmiotów legitymowanych oraz termin zawity do wytoczenia powództwa (trzydzieści dni od momentu dowiedzenia się o uchwale, nie później niż rok od jej podjęcia $)^{71}$. W sprawach nieuregulowanych przepisami art. 251 Ley de sociedades de capital stosuje się przepisy dotyczące zaskarżania uchwał walnego zgromadzenia (la junta general). Wskazany reżim znajduje zastosowanie także do uchwał rady administrującej o podwyższeniu kapitału zakładowego, podjętych na podstawie upoważnienia udzielonego przez walne zgromadzenie na podstawie art. 297 Ley de sociedades de capital.

We Włoszech natomiast ustawodawca wprowadził odrębny tryb zaskarżania uchwał rad administrujących spółek kapitałowych (il consiglio di amministrazione będących także odpowiednikiem zarządu w systemie dualistycznym) w nowelizacji Kodeksu cywilnego

66 A. Radwan, Prawo..., s. 451-452.

67 Ibidem, s. 452; v. H. Hirte et al., Großkommentar zum Aktiengesetz, Berlin 2005, komentarz do $\S 203, \mathrm{Nb} 132$.

68 A. Radwan, Prawo..., s. 452.

69 Ley de sociedades de capital, „Real Decreto Legislativo” $2010 \mathrm{nr} 1$.

70 Ustawodawca hiszpański nie przewiduje utworzenia rady nadzorczej jako odrębnego organu spółki kapitałowej, obowiązującym więc modelem jest system monistyczny.

71 V. Lecciones de derecho mercantil, red. A. Menéndez, Pampeluna 2009, s. 447-448. 
(Codice civile) ${ }^{72}$ z 2003 r. $^{73}$ Obecnie podstawą zaskarżania uchwał zarządów we włoskich spółkach akcyjnych jest art. 2388 ust. 4 Codice civile. Zgodnie z jego postanowieniami, uchwała sprzeczna $z$ ustawą lub statutem może zostać zaskarżona w terminie 90 dni od jej podjęcia. Legitymację czynną do wytoczenia takiego powództwa mają członkowie rady nadzorczej, członkowie zarządu nieobecni na posiedzeniu, na którym daną uchwałę podjęto, członkowie zarządu głosujący przeciw uchwale oraz akcjonariusze, jeżeli uchwała narusza ich prawa podmiotowe w sposób bezpośredni (soci le deliberazioni lesive dei loro diritti) ${ }^{74}$. W literaturze wskazuje się, że wyłączenie lub ograniczenie prawa poboru przez zarząd przy podwyższaniu kapitału zakładowego (na podstawie art. 2443 i 2441 ust. 4 i 5 Codice civile) może być kwalifikowane jako naruszenie praw akcjonariusza uzasadniające przyznanie mu legitymacji czynnej do wytoczenia powództwa przeciwko uchwale $^{75}$.

\section{Wnioski de lege lata i de lege ferenda}

Pomimo szerokiej kontroli procedury podwyższenia kapitału zakładowego w granicach kapitału docelowego ze strony walnego zgromadzenia, nie sposób pominąć potencjalnych zagrożeń dla sfery bezpośrednich interesów akcjonariuszy. Związane są one przede wszystkim $z$ ingerencją organów menedżerskich spółki w przysługujące im prawo poboru. W związku z tym akcjonariusze powinni zostać wyposażeni w skuteczny instrument prawny zapobiegający negatywnym dla nich skutkom uchwał naruszających prawo. W obecnym stanie prawnym środkiem takim jest przede wszystkim powództwo o ustalenie z art. 189 k.p.c., powództwo negatoryjne (actio negatoria) czy środek przewidziany przez art. 12 ust. 3 u.k.r.s. ${ }^{76}$. W literaturze wskazuje się jednak na liczne słabości wskazanych wyżej instrumentów ochrony prawnej ${ }^{77}$. W szczególności należy rozważyć problem wypośrodkowania racji akcjonariuszy z potrzebą zapewnienia bezpieczeństwa i pewności obrotu gospodarczego. Stosowanie do uchwał zarządu o podwyższeniu kapitału zakładowego w granicach kapitału docelowego przepisów o zaskarżaniu uchwał walnych zgromadzeń (art. 422 i n. k.s.h.) nie ma wprawdzie w obecnym stanie prawnym żadnego uzasadnienia, jednakże przepisy te mogą stanowić dobrą inspirację dla wysuwających wnioski de lege ferenda i, w konsekwencji, dla ustawodawcy. Wyraźne ograniczenia

72 R.D. 16 marzo 1942, n. 262 Codice Civile.

$73 \mathrm{~V}$. A. Radwan, Ł. Gorywoda, Zaskarżanie uchwat walnego zgromadzenia akcjonariuszy. Reformy w Europie i wnioski dla polskiego ustawodawcy, „Kwartalnik Prawa Prywatnego” 2009 nr 2, s. 470.

74 Cf. G.F. Campobasso, La riforma delle società di capitali e delle cooperative, Turyn 2003, s. 116;

A. Radwan, Ł. Gorywoda, Zaskarżanie..., s. 472.

75 V. F. Galgano, Diritto commerciale. La società, Bolonia 2003, ss. 309-310.

76 V. Ł. Zamojski, Wykreślenie danych niedopuszczalnych z Krajowego Rejestru Sadowego, „Monitor Prawa Handlowego" 2011 nr 2, s. 52 i n.

77 V. A. Radwan, Prawo..., s. 449-451; A. Opalski, Rada .., s. 324-327. 
podmiotowe i czasowe do wnoszenia powództwa o stwierdzenie nieważności bądź uchylenie uchwał zarządu odpowiadają na potrzebę zapewnienia ochrony akcjonariuszom $\mathrm{i}$ innym podmiotom, których prawa mogą być naruszone w procedurze podwyższania kapitału zakładowego, a także wzmacniają bezpieczeństwo obrotu ${ }^{78}$. Trzeba tu wskazać przede wszystkim na potrzebę ograniczenia kręgu uprawnionych do wytaczania takiego powództwa. W ślad za ustawodawcą włoskim można legitymację czynną przyznać tym akcjonariuszom, których prawa zostały bezpośrednio naruszone przez podjętą przez zarząd uchwałę. Doniosłe znaczenie mają także terminy do wytaczania takich powództw oraz rozgraniczenie między stwierdzeniem nieważności a uchyleniem uchwały (będącym konsekwencją naruszenia statutu). Ograniczenia czasowe i wyłączenie zastosowania art. 189 k.p.c. mogą przyczynić się do zwiększenia aktywności akcjonariuszy, którzy, będąc zainteresowani w pozbawieniu danej uchwały mocy prawnej, doprowadzą do skuteczniejszego niż dotychczas eliminowania wadliwych czynności prawnych z obrotu. Obliczanie biegu terminu od dnia dowiedzenia się przez podmiot legitymowany do wytoczenia powództwa o podjęciu uchwały odpowiada potrzebie ochrony akcjonariuszy ${ }^{79}$, zaś wprowadzenie przepisu analogicznego do art. 423 § 2 k.s.h. zapobiegnie powstawaniu zjawiska pieniactwa sądowego wśród tzw. akcjonariuszy rozbójniczych ${ }^{80}$.

Potrzeba wprowadzenia odpowiednich instrumentów służących eliminacji z obrotu prawnego wadliwych uchwał zarządów i rad nadzorczych (także tych podejmowanych w procedurze podwyższenia kapitału zakładowego w granicach kapitału docelowego) powinna skłonić ustawodawcę do interwencji legislacyjnej i opracowania nowelizacji przepisów k.s.h. Dobrą podstawą do prac legislacyjnych są obecnie obowiązujące przepisy o zaskarżaniu uchwał organów właścicielskich spółek kapitałowych i rozwiązania przyjęte przez ustawodawców innych państw ${ }^{81}$. Nadrzędnymi wartościami, które powinny przyświecać ustawodawcy w procesie legislacyjnym są ochrona interesów akcjonariuszy oraz zapewnienie bezpieczeństwa i pewności obrotu, w tym bezpieczeństwa stosunków korporacyjnych oraz interesu samej spółki. Rozwiązanie tej kwestii powinno zatem mieć charakter wyważony i kompromisowy.

78 V. A. Radwan, Prawo..., s. 450-451.

79 V. W. Popiołek et al., Kodeks spótek handlowych. Komentarz, Warszawa 2012, komentarz do art. $424, \mathrm{Nb} 1$.

80 Co do pojęcia räuberische Aktionäre w niemieckiej nauce i praktyce prawa v. A. Radwan, Ł. Gorywoda, Zaskarżanie..., s. 444 i przywołana tam literatura.

81 S. Sołtysiński i A. Opalski wskazują na to, iż „najbliższe nam systemy prawa spółek”, do jakich zaliczają prawo niemieckie, nie przewidują szczególnej procedury zaskarżania uchwał zarządów i rad nadzorczych, podając ten fakt jako argument przeciwko interwencji ustawodawcy polskiego w tę materię. Spojrzenie na systemy prawne innych państw europejskich pozwala jednak na przyjęcie odmiennej perspektywy. $V$. S. Sołtysiński i A. Opalski, Zaskarżanie..., s. 11. 


\section{SUMMARY}

\section{Resolutions adopted by the management board and the supervisory board in the process of the company's share capital increase within the limits of authorised capital}

The paper focuses on resolutions adopted by the management board and the supervisory board of a joint-stock company to increase the share capital of a public limited company within its authorised capital. The author outlines the origin and nature of the authorised capital, the content and form of the abovementioned resolutions, their legal nature and different types of possible defects in them. Challenging defective resolutions is particularly important in practice. That matter is not regulated explicitly in Polish law. The possible solutions available under Italian and Spanish regulations that are presented indicate that the challenging of defective resolutions of the management board and the supervisory board in capital commercial companies, particularly those adopted in connection with authorised capital, should also be regulated in Poland.

KEYwords: resolution, management board, supervisory board, authorised capital, challenging the resolutions 
